\title{
GUIDE TO THE DICTIONARY
}

$\mathrm{T}_{\mathrm{r}}^{\mathrm{h}}$ he first revised and expanded edition of this dictionary presents close to 14,000 idioms. Some 550 new entries containing nearly 900 new idioms, together with their variants, have been added to the body of the dictionary. Numerous idioms are polysemous, ranging from two meanings (for example, П-110 - ВСТАВИТЬ ПЕРО В БОК) to as many as eight (e.g., C-714 • B СТОРОНУ).

The dictionary is descriptive in that it reflects how the language functions. It combines, in a rather unconventional manner, features of translational and learner's dictionaries. While presenting sufficient English equivalents to cover any context a translator from Russian may encounter, it also aims to provide sufficient grammatical and explanatory information to allow the user to apply the idioms actively. In general, the dictionary is based on American usage. It is likely, though, that all speakers of English will find it useful, since most of the equivalents presented in the dictionary are common to all varieties of the English language. Speakers of Russian may also benefit from the wide variety of English equivalents presented and from the illustrations of their usage in the examples and citations.

\section{Distinguishing Features}

The dictionary contains a number of features that distinguish it from other dictionaries of Russian idioms, including those published after the original edition of this dictionary came out.

\section{Range of Entries}

It includes not only traditional idioms, but also several other types of fixed expressions not found in traditional monolingual or bilingual dictionaries of Russian idioms (see Types of Idioms under Idiomaticity, below).

\section{Grammatical Descriptions}

It includes a grammatical description for each entry, a feature generally not found in bilingual dictionaries or, with some recent exceptions, in any existing comprehensive monolingual dictionary of Russian idioms. The grammatical description provides users with the information they need to learn to use the idioms productively.

\section{Definitions}

Definitions - another feature rarely found in bilingual dictionaries - are provided for each entry in order to:

1) describe minute semantic nuances that may not be conveyed by the English equivalents alone;

2) help the user determine which sense of a polysemous equivalent is intended in the given instance;

3) provide adequate information to create a context-specific translation, should the user deem this necessary or preferable.

\section{Usage Notes}

When applicable, a usage note is provided in conjunction with (or, rarely, in place of) the definition. It describes the contexts in which the given idiom may be used and various other aspects of its usage - information that is for the most part absent in monolingual Russian dictionaries. Usage notes, like definitions, are given in English.

\section{Russian Idioms and Their Equivalents}

Sources of Russian idioms include approximately 285 works of Russian literature; numerous contexts provided by the $\mathrm{Na}-$ tional Russian Corpus; all available monolingual general dictionaries; monolingual phraseological dictionaries; surveys of Russian speakers spanning several generations; and linguistic works on Russian phraseology. In addition to the books used for the original edition, this edition has benefited from the more recent works of B. Akunin, A. Chudakov, R.D.G. Gallego, A. Lvov, V. Pelevin, V. Sorokin, T. Tolstaya, L. Ulitskaya, and A. Eppel.

The equivalents - the English phrases that suitably render the Russian idiom - are intended to cover all possible contexts in which the given idiom can occur and to offer the translator a complete picture of the semantic range of the idiom. The contextual adequacy of the equivalents was evaluated in numerous contexts: citations provided by the National Russian Corpus (including examples from colloquial speech), selected Internet texts, and illustrations in Russian monolingual dictionaries. A number of recent translations of Russian literature, including first-time translations into English and new translations of books quoted in the original edition of this dictionary, have been used for illustration (see Bibliography).

\section{Variables and Patterns}

The equivalents for verbal idioms are presented in patterns that employ the variables $\mathrm{X}, \mathrm{Y}$, and $\mathrm{Z}$ to indicate the subject, object(s), and, occasionally, location. This notation, which is widely accepted by linguists and is used in Mel'čuk and Zholkovsky's trailblazing "explanatory-combinatorial" dictionary of Russian $^{1}$ (and Mel'čuk's et al. dictionary of French ${ }^{2}$ ), has several advantages:

1) It allows for the presentation of a wide variety of equivalents that might otherwise not be presented for fear of confusion as to who is doing what, especially equivalents that reverse the Russian subject and object. For example, in Г-89 ПОПАДАТЬСЯ/ПОПАСТЬСЯ НА ГЛАЗА кому..., the use of variables allows for the inclusion of equivalents that have both $\mathrm{X}$ and $\mathrm{Y}$ as the subject:

\section{$\mathrm{X}$ попался на глаза Y-y = X caught $\mathrm{Y}$ 's eye; Y caught sight of $\mathrm{X}$; Y's eyes lighted $\langle$ lit $\rangle$ on $\mathrm{X}$...}

2) In Russian the full names of the variables employed can be declined in both the singular and the plural (X-a = икса, $\mathrm{X}-\mathrm{y}=$ иксу, X-ов = иксов, Y-a = игрека, Y-y = игреку, Y-ов = игреков, Z-a = зета, Z-y = зету, Z-ов = зетов, еtс.). Therefore, when used in patterns, the variables clearly show both the case and number of the corresponding Russian noun or pronoun. When used in the English equivalents, variables can show the possessive (X's, Y's, etc.). 
3) It allows the explicit indication of those instances in which a noun (usually one used as a direct, indirect, or prepositional object) will be plural; for example, in Г-63 ГЛАЗА РАЗБЕГАЮТСЯ $(y$ кого) the following pattern is presented:

$$
\begin{aligned}
& \text { у } \mathrm{X} \text {-а глаза разбегаются (от } \mathrm{Y}-\mathrm{-в}) \simeq \ldots \mathrm{X} \text { is dizzied by } \\
& \text { the multitude of Ys; it's more }\langle\text { there are more } \mathrm{Ys}\rangle \\
& \text { than the eyes can take in. }
\end{aligned}
$$

4) It makes possible the illustration of special constructions in which a given idiom is often used, along with the English equivalents that best translate those special constructions. That is, in addition to the basic affirmative pattern (which is presented for practically all verbal idioms), the following patterns are presented as applicable: negative, imperative, negative imperative, and verb used with a particular adverbial or adverbials. For example:

П-469 • ОСТАТЬСЯ... БЕЗ ПОСЛЕДСТВИЙ... Х остался без последствий $\simeq$ no action was taken on X...; $\| N e g$ Х не остался без последствий $\simeq$...X had its consequences $\langle$ consequence〉; $X$ took its toll (on s.o. $\langle$ sth. $\rangle)$; that was not the end of it.

Д-282 • ЗАБЫВАТЬ/ЗАБЫТЬ ДОРОГУ ... Х забыл дорогу к $\mathrm{Y}-\mathrm{y} \simeq \mathrm{X}$ stopped going 〈coming to $\mathrm{Y}$ 's place...; || Imper забудь дорогу в наш дом $\simeq$ don't bother coming back here; don't come here (ever) again...

Г-250 • ВЕШАТЬ/ПОВЕСИТЬ... ГОЛОВУ... Х повесил голову $\simeq \mathbf{X}$ lost heart...; $\|$ Neg Imper не вешай голову $\simeq$ keep your chin up!; cheer up!

Н-168 • УНОСИТЬ/УНЕСТИ НОГИ... Х унёс ноги $\simeq$ X cleared out...; $\|$ X еле 〈едва, насилу унёс $\simeq \mathrm{X}$ escaped $\langle$ got away〉 by the skin of his teeth...
While the English equivalents provided for these special patterns tend to be best used in the specified construction, all or most of the equivalents for the basic affirmative pattern can usually be used in the negative, the imperative, the negative imperative, and with many adverbials.

The variables $\mathrm{X}, \mathrm{Y}$, and $\mathrm{Z}$ cover both genders for human nouns. In those few instances when an idiom can be used only with a female (or male) subject or object, gender specifications are included in the grammatical description; for example:

В-260 • ДАВАТЬ/ДАТЬ ВОЛЮ РУКАМ... 2. [subj: usu. male]... Х даёт волю рукам $\simeq \mathrm{X}$ lets his hands wander...

C-166 • НОСИТЬ ПОД СЕРДЦЕМ кого... [VP; subj: human, female]... X носила $\mathrm{Y}$-а 〈ребёнка〉 под сердцем $\simeq$ ...X was with child...

The words "person" and "thing" are used with variables $\mathrm{X}$, $\mathrm{Y}$, and $\mathrm{Z}$ to indicate animacy/inanimacy restrictions (the word "thing" is used for all types of inanimate nouns). For example, the last equivalent in sense 2 of $\Gamma-86$ is presented thus:

Г-86 • ОТКРЫВАТЬ/ОТКРЫТЬ... ГЛАЗА кому (на кого-что) [subj: human or abstr]... Х открыл Ү-у глаза на $\mathrm{Z}-\mathrm{a} \simeq \ldots$...thing $\mathrm{X}$ was an eye opener $\langle$ eye-opener $\rangle$.

The notation "thing $\mathrm{X}$ " shows that the subject for this equivalent must be inanimate, while the grammatical brackets indicate that any inanimate subject must be abstract.

The compiler's lexicographic conservatism initially militated against the introduction of variables and patterns. In the end, however, it became obvious that the use of variables is significantly more user-friendly than the traditional one and that it tremendously expands a lexicographer's possibilities for presenting a greater number of faithful translations in a clear and understandable fashion. Feedback from users suggests they concur.

\section{PRINCIPLES, DIMENSIONS, AND ATTRIBUTES OF THIS DICTIONARY}

\section{IDIOMATICITY}

For the purposes of this dictionary, an idiom is interpreted as a nonfree combination of two or more words that acts as a semantic whole. In most cases, the meaning of an idiom cannot be predicted from the meanings of its components. An idiom is reproduced in speech as a ready-made unit, and it functions as a part of speech or an independent sentence. This dictionary includes idioms per se as well as other phrases whose idiomaticity varies in degree and type.

\section{Characteristics of Idioms}

Idioms possess the following characteristic properties, which occur in various combinations:

1) Many idioms have a defective paradigm. The defectiveness of a paradigm may involve:

a) case - for example, САМАЯ МАЛОСТЬ 'a tiny bit' is used only in the accusative case in one of its senses (самую малость)

b) number - for example, ВЫСОКИЕ МАТЕРИИ 'lofty topics 〈matters〉' is used only in the plural; ДУРНОЙ ГЛАЗ 'the evil eye' is used only in the singular c) person - for example, БОЮСЬ СКАЗАТЬ 'I'm not sure' is used only in the first-person singular; HEДОРОГО ВОЗЬМЁТ 'one won't 〈wouldn't〉 think twice about doing sth.' is not used in the first person

d) tense/aspect - for example, В МУТНОЙ ВОДЕ РЫБУ ЛОВИТЬ 'fish in troubled waters' is used only in the imperfective; МАЛО НЕ ПОКАЖЕТСЯ 'it will be worse than anyone can imagine', only in the perfective; В ЧЁМ ДУША ДЕРЖИТСЯ 's.o.'s body and soul are scarcely held together', only in the present; ПОШЛА ПИСАТЬ ГУБЕРНИЯ 'there they go', only in the perfective past

e) finite versus nonfinite forms - for example, HЕ ПРОПАДЁТ (as in За мной не пропадёт 'I will pay you $\langle$ him〉 back') has no corresponding nonfinite forms (that is, no infinitive, participle, or verbal adverb)

2) Many idioms lack some syntactic functions of the type of phrase to which they belong. For example, some noun phrases are used only predicatively: НЕ ИГОЛКА 'not exactly invisible'. Others are used only or mainly as a subject or object (that is, not predicatively): ЦЕЛЬЙ КОРОБ новостей 'a whole lot (of news)'. 
3) Some idioms are metaphorical extensions of nonidiomatic word combinations. For example, ПОДНИМАТЬ/ПОДНЯТЬ РУКУ has the literal meaning 'to raise one's hand/ arm', as well as two idiomatic meanings:

1. на кого to (try to) harm s.o. physically

2. на кого-что to criticize openly and express strong disapproval of some person, idea, policy, school of thought etc

Another such example is ГОЛОВА БОЛИТ. While it literally means 's.o. has a headache', it has the idiomatic meaning 's.o. gives himself a headache over sth.'

4) Some idioms contain a unique lexical component not found elsewhere in the language. For example, BO BCEOPУЖИИ 'fully armed', ДО СКОНЧАНИЯ ВЕКА 'till the end of time', БЕЗ УМОЛКУ 'nonstop'.

5) Some components of idioms preserve archaic grammatical forms. For example, ТЕМНА ВОДА ВО ОБЛАЦЕХ 'it is all shrouded in darkness' has the old form of the locative plural of облако - во облацех; СКРЕПЯ СЕРДЦЕ 'reluctantly' has the old form of the short active participle of the verb скрепить - скрепя (the corresponding modern form is the perfective verbal adverb скрепив).

6) The role of the negative particle HE in idioms is often unpredictable.

a) Some affirmative idioms cannot be used with negation at all: БАБУШКА НАДВОЕ СКАЗАЛА 'that remains to be seen'; КАМЕНЬ С ДУШИ СВАЛИЛСЯ 'a load was taken off s.o.'s mind'.

b) In other idioms, used only with HE, the negative particle loses its meaning of negation: KOMAP HOCA HE ПОДТОЧИТ '(it's) done to a Т'.

c) Idioms that can be used with and without negation comprise a rather heterogeneous group:

i) The use of negation may produce the antonym of the affirmative idiom: ПО ВКУСУ/НЕ ПО ВКУCY '(not) to s.o.'s taste $\langle$ liking $\rangle$ '

ii) The idiom with negation may have a different number of senses than the corresponding affirmative idiom. For example, Л-15 В ЛАДУ has only one sense, '(to be) friendly with s.o., have a good rapport with s.o.', whereas Л-16 НЕ В ЛАДУ has three senses:

1. $\sim$ скем... one is in disagreement with s.o., has a strained relationship with s.o.

2. $\sim$ с чем... one cannot understand or master sth., cannot learn how to use, apply etc sth.

3. rare $\sim c$ чем... sth. is in discord with some other thing

iii) The idiom may have the same meaning regardless of whether it is used with or without negation: (HE) ПРИШЕЙ КОБЫЛЕ ХВОСТ 'excess baggage'

7) Idioms differing only in verbal aspect may have different meanings as well as a different number of meanings. For example, Д-341 ВАЛЯТЬ ДУРАКА (the imperfective) has four meanings:

1. to pretend not to understand, know about (sth.), feign stupidity (in order to fool s.o.)

2. to act in such a way as to amuse (and occasionally annoy) others with one's tricks, anecdotes etc; behave mischievously, in a silly manner
3. to act irresponsibly, unintelligently, unseriously, make a stupid blunder

4. to be idle, spend time lazily

In contrast, СВАЛЯТЬ ДУРАКА (the perfective) has only one meaning, 'to make a blunder'. It is included at sense 3 of ВАЛЯТЬ ДУРАКА.

\section{Types of Idioms}

The overwhelming majority of entries included in the dictionary are idioms per se, or "traditional" idioms. This group includes idioms that function as a part of speech (ТЕЛЯЧЬИ НЕЖНОСТИ 'sloppy sentimentality' - noun phrase; ИЗ РЯДА ВОН ВЫХОДЯЩИЙ 'extraordinary' - adjective phrase; БЕЖАТЬ ВПЕРЕДИ ПАРОВОЗА ‘jump the gun' - verb phrase; ВКРИВЬ И ВКОСЬ 'еvery which way' - adverb phrase); and idioms that function as a sentence (БАБУШКА НАДВОЕ СКАЗАЛА 'that remains to be seen'; ТАК НЕ ПОЙДЁТ 'that won't do'). The other types of fixed expressions included in the dictionary are:

1) Phrases serving as intensifiers, restrictive markers, etc., for the words with which they collocate. This group includes:

a) pure intensifiers - for example, ДО ПОЛУСМЕРТИ 'intensely, to a very high degree'

b) negative intensifiers - for example, нужен КАК РЫБКЕ ЗОНТИК '(be as much use to s.o.) as an umbrella to a duck'

c) frozen similes - for example, красный КАК РАК '(as) red as a beet'; скользкий КАК УГОРЬ '(as) slippery as an eel'

d) phrases that consist of a word and its intensifier - for example, ВОЛЧИЙ АППЕТИТ 'a ravenous 〈voracious $>$ appetite'

2) Interjections used to express various emotions and reactions. For example, НУ И НУ! 'well, I'll be (damned)!'; НИ ФИГА СЕБЕ! 'if that don't beat all!'

3) Formula phrases, that is, fixed phrases used in common communication situations (in greeting and in parting, when apologizing or responding to an apology, when thanking s.o., etc.). For example, ВСЕГО ХОРОШЕГО 'all the best!'; НЕ СТОИТ ‘don't mention it'.

4) Grammatical, or function, idioms:

a) prepositions - for example, ПО НАПРАВЛЕНИЮ $\kappa$ кому-чему 'toward'

b) conjunctions - for example, ПЕРЕД ТЕМ КАК 'before'

c) particles - for example, ТОГО И ГЛЯДИ '(one may do sth. (sth. may happen〉) any minute now'

5) Approximately 350 commonly used proverbs and sayings that occur in Russian literature and/or colloquial speech. For example, ЯБЛОКО ОТ ЯБЛОНИ НЕДАЛЕКО ПАДАЕТ 'the apple never falls far from the tree'.

6) Some крылатье слова, or "winged words," that is, commonly used quotations from works of Russian literature and poetry. For example, БЫЛИ КОГДА-ТО И МЫ РЫСАКАМИ 'wе too had our hour of glory', from A.N. Apukhtin's poem "A Team of Bays" («Пара гнедых», 1895).

7) The dictionary follows the Russian lexicograpic tradition in including some other types of set phrases that are not strictly idiomatic, such as НЕСТИ/ПОНЕСТИ ВЗДОР (АХИНЕЮ, БЕЛИБЕРДУ ...) 'spout drivel'.

The dictionary does not include composite terms such as ЦАРСКАЯ ВОДКА 'aqua regia', БЕЛАЯ ГОРЯЧКА 'delir- 
ium tremens', АНЮТИНЫ ГЛАЗКИ 'pansy', and the like, which can be found in comprehensive general bilingual dictionaries.

\section{Etymological Groups}

Etymologically, Russian idioms include the following groups:

1) Idioms rooted in Russian reality, past and present, including the Soviet era. For example, ПОПАДАТЬ/ПОПАСТЬ ВПРОСАК 'put one's foot in it', from the old practice of using a machine called «просак» for making rope; БЕ3 СУЧКА БЕЗ ЗАДОРИНКИ 'without a hitch', from the speech of carpenters and joiners; ИСКУССТВОВЕД В ШТАТСКОМ 'plain-clothes agent', referring to a secret police agent, specifically to the KGB's widespread practice of recruiting informers during the Soviet era. The source of such idioms is explained either in an etymological note at the end of the entry, or in the definition and/or usage note.

2) Idioms based on or derived from the Bible. For example, КАИНОВА ПЕЧАТЬ 'the mark of Cain'; MАННА HEБЕСНАЯ 'manna from heaven'.

3) Idioms drawn from Greek and Roman mythology. For example, АХИЛЛЕСОВА ПЯТА ‘Achilles' heel'; АВГИЕВЫ КОНЮШНИ 'Augean stables'; ТАНТАЛОВЫ МУКИ 'the torments of Tantalus'.

4) Idioms that are full or partial loan translations of phrases from other languages. For example, КАЖДОМУ СВОЁ 'to each his own' (from the Latin suum cuique); ВЕЩЬ В СЕБЕ 'thing-in-itself' (from the German Ding an sich); СТРОИТЬ КУРЫ 'pay court to s.o.' (partial loan translation of the French faire la court).

\section{GRAMMAR}

It is assumed that the user has a basic knowledge of Russian and English grammar and grammatical terminology. There are, however, several points that deserve special attention.

The term "copula," used widely in the grammatical descriptions, is understood to embrace a rather broad group of copulalike verbs. It includes both those verbs that are regularly used as copulas (that is, оказываться/оказаться, казаться/показаться, становиться/стать, делаться/сделаться, считаться, представляться, оставаться/остаться, бывать, and являться in its copular use) and some other verbs occasionally used as copulas (сидеть, стоять, and the like).

Some idioms are used as subject-complements only with the copular быть, which takes a zero form in the present tense. This is shown in the grammatical brackets of the entry or sense as быть

Some idioms can be used both with copular быть existential or possessive быть (which can be used in the present tense in the form есть). Such idioms are presented with two patterns, one with and one without есть. For example, HA ПРИМЕТЕ has the following two patterns:

у Y-а есть на примете один 〈такой и т.п. $\mathrm{X} \simeq \mathrm{Y}$ has an $\langle\mathbf{a}$ certain, one $>\mathrm{X}$ in mind...; \| (этот) $\mathrm{X}$ у Y-а давно на примете $\simeq \mathrm{Y}$ has had an $\langle$ his $\rangle$ eye on (this $\langle$ that $\rangle$ ) $\mathrm{X}$ for (quite) some time...

The user must be aware that when a verb is used as a participle or a verbal adverb (whether as part of an idiom or not), it changes its syntactic function. Such change of function is com- mon to all Russian verbs and is therefore not specified for verbal idioms.

In the dictionary it is assumed that the grammatical subject may be in the nominative or the genitive case. This approach (suggested by a number of linguists including Mel'čuk $1974^{3}$, Chvany $1975^{4}$, and Apresjan $1980^{5}$ and $1985^{6}$ ) differs from the traditional approach, which assigns the role of subject only to noun phrases in the nominative case. In addition, a noun phrase in the genitive case is considered to function as the subject in constructions where a quantifier functions as the predicate; for example, Денег у меня кот наплакал 'I have practically no money'.

In definitions and equivalents, the English pronouns "one," "one's," and "o.s." (for "oneself") correspond to the subject of the Russian clause, while the pronouns "s.o." and "s.o.'s" (for "someone" and "someone's") correspond to the object of the Russian clause (direct, indirect, and/or prepositional). For example, the idiom УТЕРЕТЬ НОС кому... has the definition 'to outdo s.o., prove one's superiority in sth.' Here, "s.o." corresponds to the Russian indirect object комy, and "one's" refers to the Russian subject of the verb phrase. The abbreviated forms "s.o." and "sth." are used in all instances except when the phrases "someone else" and "something else" are irreplaceable elements in an equivalent, as in the case of C ЧУЖОГО ПЛЕЧА ‘...off someone else's back; someone else's castoff(s)'; НА 〈ЗА〉 ЧУЖОЙ СЧЁТ '.... at someone else's expense; ...on someone else's tab'. When the Russian verb has two objects, "s.o." or "s.o.'s" is used in reference to only one of them; the other object is referred to as a "person" (or a "thing"), "another," etc.

In looking at the equivalents for Russian patterns, one must remember that the Russian and English tense-aspect forms do not fully correspond. For example, the Russian present tense (imperfective verbs only) can be rendered by the English simple present or present progressive; the Russian perfective past can be rendered by the English simple past, present perfect, or past perfect. The English tense-aspect forms most commonly used in patterns are the simple present and the simple past, but they should be viewed as models to be modified as contexts require.

\section{ORDERING OF ENTRIES}

Each entry begins with a letter-number indicator showing its placement in the dictionary, as:

\section{П-163 • ВЫСШИЙ ПИЛОТАЖ...}

Idiomatic homographs are listed as separate entries, each of which is marked by a superscript number:

\section{П-559 • ПО ПРАВУ ${ }^{1} .$. \\ П-560 • ПО ПРАВУ ${ }^{2} .$.}

Entries are ordered alphabetically by their key words in precisely the same form as the key words are used in the idioms. For example, ИЗ РЯДА ВОН ВЫХОДЯЩИЙ is entered under РЯДА (genitive singular) rather than РЯД (nominative singular).

Whenever possible, the key word is a content word. Content words are nouns (including substantivized adjectives and participles), adjectives, numerals, main verbs, adverbs, and pronouns. If a complex particle, conjunction, preposition, or interjection has a content word, the idiom is placed under that con- 
tent word; for example, А МЕЖДУ ТЕМ '(and) yet' is placed under TEM. Idioms not containing any content word (such as many interjections and complex particles) are entered under their first word; for example, АЙ ДА 'what (a)...!' is entered under АЙ.

According to this approach, an idiomatic noun phrase is entered under its noun. An idiomatic phrase containing two nouns is entered under the first noun, regardless of the cases the nouns are in. An adjective phrase is entered under its adjective (or the first adjective, if there is more than one), and a prepositional phrase is entered under the key word of the preposition's nominal complement. When the only noun in an idiom is a proper name (personal or geographical), the idiom is listed under that proper noun; for example, КАК МАМАЙ ПРОШЁЛ 'it's as if an army had marched through (some place)' is entered under МАМАЙ.

Idiomatic verb phrases containing a noun are generally entered under the noun (or the first noun if an idiom contains more than one). For example, ПОДНИМАТЬ/ПОДНЯТЬ ПЛАНКУ 'raise the bar higher' is listed under ПЛАНКУ; ВЫХОДИТЬ/ВЫЙТИ ЗА РАМКИ ПРИЛИЧИЯ 'overstep the bounds of propriety' is listed under РАМКИ. Тhis approach has been taken for pragmatic reasons, in order to spare the user the difficulty of dealing with Russian verbal aspect. The noun in a verbal idiom is the least changeable part of the idiom; only in rare cases can it change its number and/or gender. One exception is ГОДИТЬСЯ В ОТЦЫ 〈В МАТЕРИ, В СЫНОВЬЯ и т.п.〉 'be old 〈young $\langle$ mother, son etc〉', which has changeable noun components and is entered under the verb. Verbal idioms not containing a noun are entered under the verb (or the first verb if there is more than one); for example, РВАТЬ И МЕТАТЬ 'rant and rave'.

Within a group of idioms having the same key word, idioms are arranged alphabetically word by word rather than letter by letter. For example, the entries for idioms with the key word MECTA are arranged as follows:

ВЗЯТЬ... С МЕСТА
ЖИВОГО МЕСТА НЕТ...
МЕСТА НЕ СТОЛЬ ОТДАЛЁННЫЕ
НЕ НАХОДИТЬ... (СЕБЕ) МЕСТА
НЕ СОЙТИ МНЕ... С (ЭТОГО) МЕСТА

\section{НЕ СХОДЯ С МЕСТА}

\section{HET MECTA}

\section{НИ С МЕСТА}

[etc.]

For the purposes of alphabetization, the Russian letters E and $\ddot{E}$ are treated as the same letter.

Each element in a hyphenated entry is treated as a separate word, as:

$$
\begin{aligned}
& \text { ЧTO TAM } \\
& \text { ЧТО-TO НЕ ТАК } \\
& \text { ЧТО ТЬ! } \\
& \text { ЧТО-ЧТО, А... }
\end{aligned}
$$

Optional elements in parentheses are counted in determining alphabetical order in the dictionary proper, as:

\section{(B) ПЕРВОЕ ВРЕМЯ \\ (В) ПОСЛЕДНЕЕ ВРЕМЯ \\ В СВОЁ ВРЕМЯ \\ В ТО ВРЕМЯ КАК \\ В ТО ЖЕ ВРЕМЯ}

A slightly different approach has been taken in the Index, which is explained at the introduction to the Index.

Lexical, morphological, and orthographic variants in angle brackets are not counted in determining alphabetical order, as:

\section{ПЕСЕНКА 〈ПЕСНЯ СПЕТА \\ ИЗ ПЕСНИ СЛОВА НЕ ВЫКИНЕШЬ}

For verb phrases used in both aspects, only the imperfective, which is given first, is counted in determining alphabetical order.

To ensure that the user can easily find any entry, the corpus of the dictionary is followed by an alphabetical Russian index. Each Russian entry is listed in the Index for each of its content words, and each content word is listed in the same form in which it occurs in the idiom. Verbs - both imperfective and perfective forms - are listed in the infinitive. Sayings are listed under each of the first three content words plus all other particularly important words.

\section{THE DICTIONARY ENTRY}

Each dictionary entry has the following elements: a letter-number indicator, the head matter proper (rendered in boldface capital letters), grammatical information, a definition, and one or more English equivalents. The head matter proper includes variations and optional elements that constitute the idiom(s) being presented. Most entries include some or all of the following as well: collocates; an indication of case government; style and usage labels; a usage note; a Russian pattern or patterns (for verb phrases and selected other idioms); illustrations (literary citations and/or invented examples); and an etymological note.

\section{Head Matter}

All entries are presented in their canonical variant(s), that is, in the form or forms common in Standard Russian. Regular word stress is marked for all polysyllabic words in the head matter, in synonyms presented in the various senses, and in related noun phrases. When a word or phrase allows two possibilities for stress, both are indicated: НАДЕВА́ТЬ... ПЕ́ТЛЮ́ НА СЕБЯ́; НА́ СЕ́РДЦЕ. Stress may be marked on monosyllabic words to denote phrasal stress in interjections (НУ И НУ́! 'how do you like that!') or to indicate unusual emphatic stress patterns ('́ ТЕБЕ! 'I'll teach you!').

Idioms that are synonymous with only one of the senses of a polysemous idiom do not appear in the head matter, but, rather, are listed at the applicable sense after the word "Also." For example, МЕДНАЯ ГЛОТКА '(s.o.) has a lot of lung power' is synonymous with sense 2 of Г-148 ЛУЖЁНАЯ ГЛОТКА, and so is presented at the latter as: 2. Also: МЕДНАЯ ГЛОТKA. 


\section{Noun and Adjective Phrases}

Noun phrases used only in the singular or in both the singular and the plural are listed in the nominative singular: КОСОЙ ВЗГЛЯД 'sidelong glance'. Noun phrases used only or commonly in the plural are listed in the plural: МЁРТВЫЕ ДУШИ 'dead souls'; РАБОЧИЕ РУКИ 'manpower'; АХИ И ОХИ 'ohs and ahs'. Adjective phrases used only in the singular or in both the singular and the plural are listed in the nominative singular, masculine: ВЕРНЫЙ САМОМУ СЕБЕ 'true to o.s.'

\section{Verbal Idioms}

Verbal idioms used in finite forms and in all or some of the nonfinite forms (the infinitive, participles, and verbal adverbs) are listed in the infinitive: ДУТЬ В ДУДКУ 'play s.o.'s tune'; РВАТЬ И МЕТАТЬ 'rant and rave'. If an idiom is used in both the imperfective and the perfective aspects, the imperfective is entered first, followed by a slash and the perfective: PA3МАЗЫВАТЬ/РАЗМАЗАТЬ ПО СТЕНКЕ кого 'wipe the floor with s.o.'. If only one aspectual form is listed, it means that the other aspect is not used in the given idiom or that the verb does not have an aspectual partner. For example, БИТЬ БАКЛУШИ 'twiddle one's thumbs' is listed only in the imperfective and НАВЯЗНУТЬ В ЗУБАХ 'bore s.o. to death' is listed only in the perfective, because neither of these verbs has an aspectual partner. Verbal idioms that are used only in finite forms are generally listed in the third-person singular present and perfective past forms (and have sentential definitions): БРОСАЕТ/БРОСИЛО В КРАСКУ... 's.o. flushes out of shame, embarrassment'. If no restrictions are stated, such idioms can be used in the future tense as well. Future-tense forms are presented in the head matter only for idioms that are used exclusively or predominantly in the future tense (usually the perfective future): НЕДОРОГО ВОЗЬМЁТ 'one won't $\langle$ wouldn't $\rangle$ think twice about doing sth.' Idioms used only in one finite form are listed in that form: НЕ КАПЛЕТ 's.o. is not in any rush'; БОЮСЬ СКАЗАТЬ 'I'm not sure'. Idioms with one component functioning as the subject are presented in sentential form: ДУША УХОДИТ/УШЛА В ПЯТКИ 's.o.'s heart sinks into his boots'; УДАР ХВАТИЛ кого 's.o. had a seizure'.

An idiom containing the word HET used as a predicate is described as a verb phrase (shown as VP). Numerous idioms with HET are presented only in their present-tense form: ИЗНОСУ НЕТ чему 'sth. doesn't wear out'. If no restrictions are stated for such idioms, they can be used in the past (не было) and future (не будет) tenses as well.

Idioms used only or most commonly in the negative are listed in the negative. Most idioms presented in the negative can never be used without negation: НЕ ВЫХОДИТ 〈НЕ ИДЁТ, НЕЙДЁТ \ ИЗ ГОЛОВЫ 's.o. can't get sth. out of his mind'; НЕ ЗНАТЬ... ПОКОЯ 'know no peace'; НЕ ОСТАВАТЬСЯ/НЕ ОСТАТЬСЯ В ДОЛГУ 'pay s.o. back (in kind)' Some idioms, however, while generally negative, can occa sionally be used without negation; they are described as "used without negation to convey the opposite meaning."

\section{Collocates and Case Government}

For idioms with a limited range of collocates, the collocates (or the most typical of them) are listed, for example: C BEPХОМ налить, наполнить, насыпать что '(fill, pour sth.) to the brim'. When collocates differ for different senses of a polysemous idiom, they are listed separately in each sense, as at H-240 HOCOM K HOCY:

1. столкнуться, встретиться... (to meet, run into one another) right up close, facing one another...

2. увидеть кого-что и т.п. (to see s.o. or sth.) at close proximity...

Case government for both the main entry and its collocates is shown by the forms кого-чего, кому-чему, к кому, кчему, etc. Кого, кому, etc., must be replaced by human (or, occasionally, animal) nouns, whereas чего, чему, etc., can be replaced by inanimate or collective nouns, as: НЕ ПАРА кому 'one is not a (good) match for s.o.'; ПО СЕБЕ (sense 1) найти, выбрать кого-что '(to find, choose s.o. or sth.) coinciding with one's taste, of one's preference, commensurate with one's abilities, status etc'.

In instances when the main entry includes two or more synonymous idioms with the same government or collocates, the collocates and government are shown with the first idiom only, implying that they carry over to successive idioms. For example, $\Gamma-94$ contains three synonymous idioms with the same government and collocates:

\section{ПУЩЕ ГЛАЗА беречь кого-что, хранить что; ПАЧЕ ГЛАЗА $\langle$ ОКА $\rangle$ obs...}

If the verbal government differs for variants or synonyms, it is provided for each one, as: ПОКАЗЫВАТЬ 〈УКАЗЫВАТЬ, ТЫКАТЬ ПАЛЬЦЕМ... (на кого-что); ТЫКАТЬ ПАЛЬЦЕМ... в кого.

The head matter for verbal idioms does not include related noun phrases; these are shown after the verbal equivalents following the symbol $\circ$.

\section{Proverbs and Sayings}

Proverbs and sayings are given in their canonical forms. If part of a saying is used as an independent idiom, it is presented as a separate entry. For example, the saying ЛУЧШЕ СИНИЦА В РУКАХ, ЧЕМ ЖУРАВЛЬ В НЕБЕ 'a bird in the hand is worth two in the bush' has two offshoot idioms: СИНИЦА В РУКАХ 'the proverbial bird in the hand' and ЖУРАВЛЬ В HЕБЕ '(like) the proverbial two birds in the bush'. The full saying is given as one entry (at C-220), and each of its offshoots is entered separately (C-221, Ж-92) with a note referring the user to the full saying.

\section{Usage Labels}

Usage labels are provided for Russian idioms only. When provided, usage labels follow the idiom to which they refer, whether it is located in the head matter of the entry or only at a given sense. The label or labels apply as well to any lexical variants, morphological variants, or synonymous idioms that appear in angle brackets. For example, in К-65 НА КАПЛЮ $\langle$ НА КАПЕЛЬКУ $\rangle$... coll '(hardly) an ounce (of...)', the label coll refers to both КАПЛЮ and the КАПЕЛЬКУ variant. If synonymous idioms that are separated by a semicolon take the same usage label, it is preceded by the word "both" (for two variants) or "all" (for three or more variants). For example, the label all coll at C-527 refers to all four cited variants of the idiom:

ПО СОВЕСТИ ${ }^{2}$; ПО СОВЕСТИ ГОВОРЯ 〈СКАЗАТЬ, ПРИЗНАТЬСЯ $>$ all coll... speaking openly... 
A label is placed within the angle brackets when it refers only to the variant inside those brackets. For example, the label obs at Л-71 refers only to the variant В РЕКУ ЗАБВЕНИЯ:

КАНУТЬ В ЛЕТУ 〈В РЕКУ ЗАБВЕНИЯ $o b s\rangle l i t .$. to disappear completely, be forgotten forever...

Usage labels fall into three main categories: temporal, stylistic, and emotive-expressive.

Stylistic and emotive-expressive labels should be seen as general, not absolute, guidelines for the interpretation and use of an idiom, since the nuances that an idiom can convey depend largely on contextual factors. One exception in this regard is the type of label attached to expletives. To help English speakers correctly understand the sociolinguistic usage of phrases that go far beyond the boundaries of standard literary Russian, the dictionary provides a number of "prohibitive" labels.

Temporal labels indicate an idiom's standing in relation to contemporary usage. These are the temporal labels used in the dictionary:

obs (obsolete) - The idiom is not generally used in contemporary literary or colloquial Russian; it may be used strictly for stylization purposes.

obsoles (obsolescent) - The idiom is used rarely in contemporary literary or colloquial Russian and is perceived as becoming out of date.

old-fash (old-fashioned) - The idiom is used only or chiefly by older people.

rare - The idiom is used rarely and may be perceived as somewhat unusual.

recent - The idiom is typically perceived as relatively recent.

Stylistic labels indicate the stylistic register of an idiom. Russian idioms presented without a stylistic label are stylistically neutral, meaning that they can be used under any circumstances and with any interlocutor. Two major factors have been considered in the assignment of stylistic labels: first, the circumstances in which an idiom can typically be used (a friendly conversation or letter, an official gathering, etc.); second, the ages and relative social status of the speaker, his interlocutor, and the person(s) referred to. While no stylistic labels are provided for English equivalents, an effort was made to find equivalents that are as close as possible to the stylistic register of the Russian. The following stylistic labels appear in the dictionary:

coll (colloquial) - The idiom is used in casual or informal speech and writing.

highly coll (highly colloquial) - The idiom is used in very casual speech and writing and is often colored by the speaker's emotive attitude; highly colloquial idioms are inappropriate in formal or semiformal situations.

substand (substandard) - The idiom is characterized by a deviation from grammatical or syntactical standards and/or by having a vernacular word as one of its components; it is used by less educated or uneducated people.

slang - The idiom has come into the spoken language from, or is still used predominantly in, the speech of a specific social group, profession, age group, etc. Such idioms are used in extremely casual speech; they are often metaphorical and sometimes sexually suggestive. euph (euphemism) - The idiom is used as an inoffensive substitute for a vulgar, blasphemous, or shocking expression.

iron (ironic) - The idiom is used in a meaning opposite to its direct meaning.

lit (literary) - The idiom is characteristic of educated, wellread people and is used mainly, albeit not exclusively, in learned conversation and formal speech and writing (public speeches, scholarly essays, etc.).

rhet (rhetorical) - The idiom is used with the intention of producing a certain effect on the listener(s) or reader(s). It occurs mainly, but not only, in declamatory speech or in exhortative speech and writing.

elev (elevated) - The idiom is used in exalted (sometimes stilted) writing or very formal speech.

offic (official) - The idiom is used in formal, official contexts and/or belongs to bureaucratic jargon.

special - The idiom is used only or predominantly in specialized contexts.

folk poet (folkloric poetic) - The idiom comes from popular lore, especially folk tales, and preserves to some degree or other its folkloric, poetic overtones.

vulg (vulgar) - The idiom is socially or aesthetically in bad taste, or is generally considered indecent or obscene.

taboo - The idiom directly refers to sexual and/or scatological practices, and is unacceptable in standard contexts.

Occasionally, synonymous idioms of two different registers are grouped together in the same head entry, as: ГОЛОВА ВАРИТ ( $y$ кого) coll; КОТЕЛОК ВАРИТ substand; МОЗГИ BAPЯT substand... 's.o. is bright, intelligent'. An attempt has been made to provide equivalents covering all stylistic registers presented in the entry.

Emotive-expressive labels describe the emotions commonly conveyed by the given idiom. The intensity of these emotions, expressed particularly clearly in colloquial speech, may be affected by such factors as the speaker's frame of mind, the relationship between the speaker and the interlocutor, and the status of the party to whom the idiom refers (the speaker himself, the interlocutor, or a third party). These are the emotiveexpressive labels appearing in the dictionary:
humor (humorous)
iron or humor, humor or iron - Said with ironic or humor- ous intonation; the prevailing emotion comes first.
disapprov (disapproving)
derog (derogatory)
condes (condescending)
impol (impolite)
rude

\section{GRAMMATICAL INFORMATION}

The grammatical description is intended to supply the basic information needed to use an idiom actively in speech and writing. The majority of the terminology in the grammatical descriptions should be familiar to anyone who has studied a foreign language; exceptions are specified below.

The grammatical description appears within square brackets [ ] and refers to the Russian idiom and its variants and/or synonyms as presented in the head matter. If an idiom's variants and synonyms differ in structure and/or syntactic function 
from the main form, a description of each variant/synonym is provided. When different senses of a polysemous idiom require different grammatical information, grammatical brackets are included at each numbered sense.

An idiom is described according to its phrase type in those instances when it is used in all or most of the syntactic functions characteristic of the given type of phrase. The phrase types referred to in the grammatical brackets are NP (noun phrase), VP (verb phrase), AdjP (adjective phrase), AdvP (adverb phrase), and PrepP (prepositional phrase). To avoid complicating the grammatical description, the following labels are used as umbrella terms: NP encompasses both a noun and a noun phrase; VP both a verb and a verb phrase; and so on. (These grammatical labels and their syntactic parameters are described separately below.)

When an idiom is "frozen" and the description of the type of phrase (if altogether possible) would in no way help the user to apply it correctly, it is described either as "Invar" (invariable) or as "these forms only." "Invar" indicates that the single form presented in the head matter is the only form used: $Г-429$ ГРУДЬ В ГРУДЬ [Invar; adv]. The label "these forms only" indicates that the multiple variants presented in the head matter are the only forms used: Д-305 ДОХНУТЬ 〈ДЫХНУТЬ КОГДА [these forms only; impers predic with быть labels "Invar" and "these forms only" are also used to describe sentential idioms that are used only in the form or forms listed in the head matter: Б-6 БАБУШКА (ЕЩЁ) НАДВОЕ СКАЗАЛА 〈ГАДАЛА [these forms only]. These two labels do not imply anything about the linear order of the components of an idiom, which is described separately.

When an idiom requires an object or complement to perform a specific syntactic function, its grammatical description includes an indication of the required object or complement: М-32 ПОД МАРКОЙ чего [...the resulting PrepP is adv].

When an idiom functions only as a subject-complement, it is described in grammatical brackets as "subj-compl." In some instances, an idiomatic subject-complement can be used only with быть быть ${ }_{\varnothing}$." In other instances, an idiomatic subject-complement can be used with other copular verbs, in which case it is described as "subj-compl with copula."

When an idiom that functions as an object-complement can be used only with a specific verb or verbs, the grammatical brackets specify that verb or those verbs:

Ж-40 • В ЖИВЫХ [PrepP; Invar; subj-compl with быть остаться (subj: human) or obj-compl with застать (obj: human)]...

When an idiom that is not fixed in form (not "Invar" or "these forms only") is used as a subject- or object-complement, its gender and number are controlled by the subject or object, respectively.

\section{Noun Phrases}

As stated above, an idiom is described as "NP" when it is used in all or most of the typical syntactic functions of a noun phrase; that is, as a subject, an object, and a complement. For idioms in which one noun governs another or others, NP refers to the key word of the idiom: ГЕРОЙ ДНЯ 'the hero of he hour'; КНИГА ЗА СЕМЬЮ ПЕЧАТЯМИ 'a closed book'; ПАРА ПУСТЯКОВ 'child's play'. Grammatical brackets indicate when an idiom is used only or predominantly in one or two of the above functions: К-313 ЦЕЛЫЙ КОРОБ [NP; sing only; subj or obj]. Grammatical brackets also indicate when an idiom is usually (or often) used as a vocative or appositive: Г-225 ШАЛЬНАЯ ГОЛОВА [NP; usu. appos, vocative, or subj-compl with copula (subj: human)].

Restrictions are provided for noun phrase idioms that are used only in one grammatical case; for example, sense 2 of М-18 САМАЯ МАЛОСТЬ... 'a tiny bit' has the restriction "accus only" (sense 1 has no restrictions with regard to case).

Restrictions are also given for noun phrase idioms used only in the singular or only in the plural: В-290 АДМИНИСТРАТИВНЫЙ ВОСТОРГ [NP; sing only] 'bureaucratic zeal'; Д-401 МЁРТВЫЕ ДУШИ [NP; pl only] 'dead souls'. Such restrictions are not presented for idioms whose key noun is used in the language only in the singular or only in the plural: Г-327 ГОРЕ ЛУКОВОЕ '(уоu) lummox' and Т-56 ТАРЫБАРЫ 'tittle-tattle'.

For idioms comprised of two nouns connected by a conjunction, the grammatical restriction "sing only" refers to each noun component of the idiom: ЦАРЬ И БОГ 'lord and master'; АЛЬФА И ОМЕГА 'the alpha and omega'. Similarly, АХИ И ОХИ 'оhs and ahs' is described as "pl only," which means that each of its components may be used only in the plural.

For idioms consisting of a noun in the nominative case plus another element, the restriction "sing only" or "pl only" refers only to the noun in the nominative case. It is understood that the remaining component(s) of the idiom can be used only in the form or forms shown in the head matter: for example, in the idioms ДОЛЯ ПРАВДЫ 'grain of truth' and ПРЕВРАТНОСТИ СУДЬБЫ 'vagaries of fate', the indicators "sing only" and "pl only" refer only to the words ДОЛЯ and ПРЕВРАТНОСТИ, respectively.

When a noun phrase that is used as a subject-complement can occur both in the nominative and in the instrumental case, the noun phrase is described as "subj-compl with copula, nom or instrum"; for example:

В-235 • ВОЛК В ОВЕЧЬЕЙ ШКУРЕ... [NP; usu. subjcompl with copula, nom or instrum (subj: human)...] ...wolf in sheep's clothing.

\section{Adjective Phrases}

Adjective phrases (including participles) that contain longform adjectives are presented in the nominative case only, in the masculine singular: ЦЕЛЫЙ И НЕВРЕДИМЫЙ 'safe and sound'. Adjective phrases that contain short-form adjectives are listed in the masculine singular: НИ ЖИВ НИ МЁРТВ 'more dead than alive'. If no restrictions are provided, the given adjective phrase can be used in other genders, in the plural, and (long-form only) in other cases as well.

An adjective phrase that can be placed only before or only after the word or phrase it modifies is described as "premodif" (premodifier) or "postmodif" (postmodifier), respectively.

An adjective phrase that is used as a subject-complement with a plural subject only is listed in the plural: ОДНИМ МИРОМ МАЗАНЫ 'tarred with the same brush'. An adjective phrase used as a subject- or object-complement is described similarly to a noun phrase used in these functions. For example, НЕ ЛИШНЕЕ 〈НЕ ЛИШНЕ〉 'it wouldn't be (such) a bad idea (to do sth.)' is described as:

[AdjP; subj-compl with бытьø (subj: usu. infin or a clause) or obj-compl with находить, считать (1st var. only, obj: usu. deverbal noun or infin)] 


\section{Verb Phrases}

A verb phrase is described as "VP" when it can be used in all or at least some finite and non-finite forms: ВЛЕЧЬ/ПОВЛЕЧЬ ЗА СОБОЙ что 'lead to (sth.)'.

Verbal idioms that function as predicates require that a subject (and often an object or objects) be added to them to create a complete utterance. To help the user apply such idioms actively, the grammatical brackets indicate the type(s) of subject(s) and, if relevant, object(s) with which the given idiom is used: human noun, personal or geographical name, animal noun, collective noun, concrete noun (understood as denoting a thing), abstract noun, infinitive, and clause. For example, В-196 ЛИТЬ ВОДУ НА МЕЛЬНИЦУ чъю, кого 'be grist to s.o.'s mill' has a human or abstract subject and is described as "VP; subj: human or abstr." When an idiom can be used only with a specific thematic group or a limited number of nouns as subjects and/or objects, this restriction is indicated:

К-116 • КАШИ ПРОСЯТ... [VP; subj: a noun denoting heavy, sturdy footwear or individual parts of shoes...] s.o.'s boots (shoes etc) are in bad condition, in need of repair...

К-97 • СТАВИТЬ/ПОСТАВИТЬ НА КАРТУ что [VP; subj: human or collect; obj: abstr (usu. жизнь, честь etc)] to risk one's life, reputation, security etc in the hope of winning or gaining sth...

Д-7 • ДАВАТЬ/ДАТЬ СЕБЯ ЗНАТЬ... [VP; subj: abstr or concr...] to manifest itself, become noticeable...

P-170 • НА РОДУ НАПИСАНО... [AdjP; subj-compl with быть preordained for s.o...

Restrictions are provided for verb phrases and sentences that are used only or usually in the specified tense-aspect and/or person form(s):

К-117 • МАЛО КАШИ ЕЛ/СЬЕЛ... [...2nd or 3rd pers; past only...] one is (too) inexperienced, young etc (for sth.)...

В-225 • НЕДОРОГО 〈НЕ ДОРОГО [...fut only...] one will do sth. (sth. bad, reprehensible, as denoted by the preceding verb) readily, without hesitation...

К-46 • КАМЕНЬ... С ДУШИ (С СЕРДЦА) СВАЛИЛСЯ у кого [...usu. past] s.o. experienced a sense of relief, felt liberated from his worries...

Some idioms are used only or predominantly in the generic «ты» form, perfective future. This feature is indicated in the grammatical brackets, along with the verb form itself:

К-35 • КАЛАЧОМ НЕ ЗАМАНИТЬ... [...usu. fut gener. 2nd pers sing не заманишь...] to be unable by any means to convince s.o. to go to some place or see s.o....

In those rare instances in which a verbal idiom consists of two verb forms, only one of which conjugates, the grammatical brackets specify "only verb conjugates":

Д-329 • И ДУМАТЬ ЗАБЫТЬ... [...only забыть conjugates...] to stop thinking about s.o. or sth....

Some infinitival idioms do not act as regular verb phrases in that they do not conjugate and are used only as the complement of given predicates. The entries for such idioms indicate the type of predicates with which the idiom can be used. For example, С-318 ДВУХ СЛОВ СВЯЗАТЬ, which is not used as a regular verb phrase, is presented as follows:
С-318 - ДВУХ СЛОВ СВЯЗАТЬ не мочь, не уметь и т.П. [VP; infin subj-compl with не мочь, не уметь (subj: human)] to be unable to speak or express one's thoughts coherently...

Verb phrases that are often or most commonly used in the third-person plural with an omitted subject are described as "3rd pers pl with indef. refer." For example, К-174 ПУСКАТЬ/ПУСТИТЬ КОЗЛА В ОГОРОД is such an idiom, and has the above grammatical description as well as the following illustrative pattern:

пустили козла в огород $\simeq$ they put the cow to mind the corn; they put the wolf in charge of the sheep...

\section{Idioms Functioning as Adverbials}

Idioms that function as adverbials are divided into two groups based on their function. The first group, labeled "adv" (adverbial), comprises adverbials of manner, time, space, degree, cause, etc. The second group, labeled "sent adv" (sentence adverbial), comprises adverbial idioms that refer to the sentence or clause as a whole and are syntactically more detached from the elements of the sentence than adverbials belonging to the first group. Sentence adverbials may do the following:

* Indicate a manner of speaking (МЯГКО ВЫРАЖАЯСЬ 'putting it mildly'

* Express an emotion or a value judgment (K HЕCЧAСТЬЮ 'unfortunately'; НА ДЕЛЕ 'in deed')

* Convey modality (ОТКРОВЕНHO ГОВОРЯ 'frankly speaking')

* Anticipate the possibility that something might happen (ЧЕГО ДОБРОГО 'for all one knows, s.o. 〈sth.) might...')

* Emphasize a statement or one of its parts (ЕСЛИ ХОТИTE 'if you will'; МОЖНО СКАЗАТЬ 'one might say')

* Play an organizing role in a text or speech in various ways:

1) by connecting two halves of a statement by means of a contrast (С ОДНОЙ СТОРОНЫ... С ДРУГОЙ СТОРОНЫ... 'on the one hand... on the other [hand]')

2) by marking a transition to a new topic (КСТАТИ СКАЗАТЬ 'incidentally')

3) by introducing a summary (В ЗАКЛЮЧЕНИЕ 'in conclusion'), a specification (К ПРИМЕРУ 'for example'), a result (В РЕЗУЛЬТАТЕ 'as a result'), and so forth.

Most of the idioms used as adverbials or sentence adverbials cannot change in form and are therefore described as "Invar; adv," "Invar; sent adv," "these forms only; adv," or "these forms only; sent adv."

The grammatical brackets note when an idiom functioning as an adverbial occurs only or mainly with one verbal aspect:

В-12 • ВДОЛЬ И ПОПЕРЁК... 1. [more often used with pfv verbs] ...far and wide...

Г-48 • ВО ВСЕ ГЛАЗА... [...used with impfv verbs...] ...all eyes...

There are some idiomatic Russian adverbials which, although positive in form and used with non-negated verbs, are negative in meaning; each such adverbial is described as "neg intensif" (negative intensifier). For example, разбираться... в чём КАК СВИНЬЯ В АПЕЛЬСИНАХ, literally 'to under- 
stand sth. like a pig understands oranges', means 'to understand absolutely nothing (with regard to sth.)'.

Adverbials used only with a negated predicate are described as "used with negated verbs." This group of idioms consists mainly of НИ idioms such as НИ ЗА КАКИЕ БЛАГА (В МИРЕ) 'not for anything (in the world)'. The definitions for these idioms include an English negation (usually "not"), which corresponds to the combination of НЕ and НИ.

In adverbials of the type как + adjective (КАК ОШПАРЕННЫЙ 'as if one had been scalded') and как + noun (КАК БАРАН 'like a mule'), the adjective and noun, respectively, are always in the nominative case. Therefore such idioms are described as "nom only." These idioms are co-referential with the subject (or, less commonly, the object), and their adjectival or nominal components must agree with the subject or object in gender (adjectives only) and number (both adjectives and nouns).

\section{Quantifiers}

Quantifiers may function as predicates and/or adverbials. Quantifiers that function predicatively are described as "quantit subj-compl" (quantitative subject-complement). Some predicative quantifiers can be used only with бытьø and are described as "quantit subj-compl with быть." Other predicative quantifiers can be used with a number of copular verbs and are described as "quantit subj-comp with copula." For example, КОТ НАПЛАКАЛ 'practically no... (at all)' and ХОТЬ ЗАВАЛИСЬ 'lots 〈a lot〉 of' are described as "quantit subj-compl with copula."

Quantifiers that function as adverbials-for example, KAK НА МАЛАНЬИНУ СВАДЬБУ '(cook) enough for an army'are described as "adv (quantif)."

\section{Interjections}

The label "Interj" (interjection) describes idioms that express the speaker's emotional attitude toward, or emotive evaluation of, the person, thing, situation, etc., in question. Interjections are syntactically independent structures that can express different, and sometimes even opposite, emotions depending on the context and the speaker's intonation; for example, ЁЛКИПАЛКИ can express annoyance, admiration, delight, surprise, and bewilderment, among others.

\section{Formula Phrases}

The label "formula phrase" describes situationally conditioned idioms used in communicative contexts. Such idioms are often referred to as "speech etiquette formulae" in Russian sources. They are used in greeting (СКОЛЬКО ЛЕТ, СКОЛЬКО ЗИМ! 'it's been ages!'), at parting (ВСЕГО ХОРОШЕГО 〈ДОБРОГО $\$ ! 'all the best!'), when wishing someone something (СЧАСТЛИВОГО ПУТИ! 'have a good trip!'), in making a request (БУДЬ ДОБР 〈БУДЬТЕ ДОБРЫ〉 'be so kind as to...'), in expressing gratitude (ПОКОРНО БЛАГОДАРЮ, sense 1, 'I humbly thank you'), in responding to an expression of thanks (HЕ СТОИТ 'don't mention it'), and the like.

\section{Sentential Idioms}

Sentential idioms fall into three basic groups:

1) Idioms that need only a direct, indirect, or prepositional object to become a complete sentence. For example, in order to become a complete sentence, НОГИ НЕ ДЕРЖАТ кого 's.o.'s legs won't support him' requires a direct object, and ВРЕМЯ РАБОТАЕТ на кого 'time is on s.o.'s side' re- quires a prepositional object. Such idioms are described as "VP ${ }_{\text {subj, }}$ " which means that they contain both the subject and the predicate (or part of the predicate).

2) Idioms that need бolm , $_{ø}$ or another copular verb (and often an object) to become a complete sentence. Such idioms are described as "VP subj with быть " or "VP for example, ГАЙКА СЛАБА $у$ кого 's.o. doesn't have it in him (to do sth.)' is described as "VP ${ }_{\text {subj }}$ with copula."

3) Idioms that are complete sentences as they are listed. Such idioms are described as "sent." This group includes numerous sayings, adages, and крылатые слова ("winged words"), as: БАБУШКА НАДВОЕ СКАЗАЛА 'that remains to be seen'; РУКОПИСИ НЕ ГОРЯТ 'manuscripts don't burn'. Generally, such idioms can function in all or some of the following ways: as an independent sentence, as a clause in a compound sentence, or as the main or subordinate clause in a complex sentence. Exceptions are specified.

\section{Sayings}

All proverbs and sayings are described as "saying" since, for the purposes of this dictionary, the difference between a proverb and a saying is irrelevant.

\section{Word Order}

When an idiom has a free order of elements, no reference to word order (WO) is made in the grammatical description. However, when an idiom has a fixed order of elements, it is described as "fixed WO," as in КАЛАНЧА ПОЖАРНАЯ [...fixed WO] 'beanpole'.

When the order of an idiom's components can be changed only in rare cases, the idiom is described as "usu. this WO."

When only one component of an idiom can change its position (and the rest cannot), this information is provided, as:

К-37 • ДОВОДИТЬ/ДОВЕСТИ ДО БЕЛОГО КАЛЕНИЯ... [...the verb may take the final position, otherwise fixed WO] to irritate s.o. past the limits of his endurance, make s.o. lose his self-control completely...

Д-11 • ДОРОГО БЫ ДАЛ... [...fixed WO with бы movable] one would be willing to give up, sacrifice sth. of great value in order to get sth. he really wants or make some desired event happen...

In the second example the grammatical description shows that бы can be placed before ДОРОГО or after ДАЛ.

When the word order of a noun phrase can change only when the noun phrase is used in a specified syntactic function, this information is provided: for example, ВОЛЧИЙ АППЕТИТ [fixed WO except when used as $\mathrm{VP}_{\text {subj }}$ with copula] (as in Он ел с волчьим аппетитом 'He ate with a ravenous /voracious $>$ appetite', but Аппетит у него волчий 'He has a ravenous $\langle$ voracious $\rangle$ appetite').

Since "grammatical" idioms (conjunctions and prepositions) and hyphenated idioms always have fixed word order, the label "fixed WO" is not provided for them.

The labels "fixed WO" and "usu. this WO" apply to the idiom per se only and do not take into account placement of the copula, collocate(s), object(s), etc., whose typical placement is shown in patterns and citations.

It should be understood that even when a given idiom has fixed word order in standard literary and colloquial usage, this does not exclude its occasional use with a different word order in poetry, in utterances with shifted emphasis, or by an individ- 
ual speaker or author for stylistic purposes. Thus, the idioms ОТ ПОЛНОТЫ ДУШИ (СЕРДЦА) 'from the fullness of one's heart' and НА ГОЛОДНЫЙ ЖЕЛУДОК 'on an empty stomach' are assigned the label "fixed WO" despite the existence of such well-known nineteenth-century citations as «Дай, обниму тебя от сердца полноты», "Let me embrace you now, from the fullness of my heart" (A.S. Griboedov) and «И кому же в ум пойдет на желудок петь голодный!», “And who would even think of singing on an empty stomach?" (I.A. Krylov).

\section{Definitions ANd USAGe Notes}

The definition and, where applicable, usage note are placed directly after the grammatical brackets. When possible, the definition is presented in the same form as the defined Russian idiom, that is:

* as a noun phrase for a Russian noun phrase: ВЛАСТИТЕЛЬ ДУМ [NP...] 'a person who has much influence on his contemporaries, an intellectual and spiritual leader'

* in the infinitive for a regular verb phrase presented in the infinitive: СЫГРАТЬ В ЯЩИК [VР...] 'to die'

* as an adjective phrase for a Russian adjective phrase: ЦЕЛЫЙ И НЕВРЕДИМЫЙ 〈ЦЕЛ И НЕВРЕДИМ〉 [AdjP...] 'unhurt, in fine condition'

* as an adverb for a Russian idiom functioning as an adverbial: НЕЖДАННО-НЕГАДАННО [AdvР...] '(to appear, arrive etc) suddenly, unexpectedly'

Idioms that function as sentences have sentential definitions; for example: БАБУШКА НАДВОЕ СКАЗАЛА... 'it is yet unknown whether the event in question will happen or not (usu. the implication is that it will not happen)'.

In entries with two or more senses, each sense has its own definition, placed after the Arabic numeral introducing the sense.

Definitions and usage notes use generic "he" to refer to both sexes. In usage notes, "of" generally introduces the subject of the Russian phrase or the person or thing modified by the phrase; "in refer. to" indicates the object of the Russian phrase or the general situation surrounding the use of the idiom. For example:

М-153 - СИДЕТЬ МЕШКОМ на ком... (of a garment that is too large, wide etc) to fit poorly...

Л-58 • КТО В ЛЕС, КТО ПО ДРОВА... (often in refer. to singing and playing musical instruments) (people do sth.) without coordination among themselves, without agreement, cooperation...

\section{Collocates in Definitions}

The translations of collocates are generally given in parentheses as part of the definition. However, in those rare cases in which different collocates would require different wordings of the definition, the collocates are not included in the definition; for example: П-493 отдать на ПОТОК И РАЗГРАБЛЕНИЕ что; предать ПОТОКУ И РАЗГРАБЛЕНИЮ что... 'complete destruction and widespread looting (of some place, country etc)'. Usage of the collocates is then shown in patterns:

X-ы отдали Y на поток и разграбление $\simeq$ Xs surrendered $Y$ to be ravaged and plundered 〈pillaged and ru- ined>; || X-ы предали Y потоку и разграблению $\simeq \mathbf{X s}$ ravaged and plundered $\langle$ pillaged and ruined $\rangle \mathrm{Y}$.

\section{Prepositions, Conjunctions, Particles}

No definition per se has been provided for most complex prepositions, complex conjunctions, and particles; instead, there is a usage note describing the relationship between the element(s) associated with the idiom and other elements of the context. In those cases where a definition per se has been provided, it follows the usage note. Some typical descriptions are:

* used to indicate the unexpected nature of the action that follows

* used to introduce a clause, phrase etc whose information adds to, and is more important than, the information in the preceding statement

* used to show that the situation or action presented in the main clause immediately follows the situation or action presented in the subordinate clause

* used to show that the truthfulness or realization of what is stated in the main clause is contingent upon the fulfillment of the condition stated in the subordinate clause

\section{Interjections}

Interjections are described in terms of the emotions they can convey; for example: НУ И НУ! 'used to express surprise, delight, displeasure, an ironic attitude etc.'

\section{ENGLISH EQUIVALENTS}

The overwhelming majority of entries contain more than one English equivalent, since different contexts often require different translations of a given idiom. When a Russian idiom has several English equivalents, those that are most broadly applicable (or most similar to the Russian) are presented first, and those that are most restricted are presented last. Equivalents in a given entry may differ stylistically in order to cover nineteenth- as well as twentieth- and twenty-first-century contexts.

Whenever possible, equivalents are presented in the same form as the Russian idiom, that is, an English noun phrase for a Russian noun phrase, an English verb phrase for a Russian verb phrase, and so forth. Equivalents for Russian idioms that function as complete sentences are presented in sentential form.

The notation "Cf." (which when given follows the last English equivalent in an entry) is used to introduce English idioms and sayings that, although not suggested for purposes of translation, provide insight into the meaning of the Russian idiom. Often such phrases (as "every Tom, Dick, and Harry" for КАЖДЫЙ 〈ВСЯКИЙ〉 ВСТРЕЧНЫЙ 'anyone and everyone') have a distinct national flavor, include typical American or British names, and the like. However, not all culturally bound elements are reserved for "Cf." Since substantial Russian communities can be found in English-speaking countries, the terms "ruble" and "kopeck," for example, are included with "penny," "dime," etc., in numerous English equivalents.

\section{Collocates in Equivalents}

In cases when it is impossible to present the English equivalent of a Russian idiom without collocates, the collocates are provided along with the equivalent (in parentheses, when possible). For example, many adverbial intensifiers cannot be translated without a verb. In such cases, the English equivalents are 
presented with their collocates, occasionally in a pattern, as in (И) В ГЛАЗА не видал, не видел...: Х (и) в глаза не видел $\mathrm{Y}-\mathrm{a} \simeq \mathrm{X}$ has never set $\langle$ laid $\rangle$ eyes on $\langle$ upon $\rangle \mathrm{Y} .$. .

\section{Infinitives}

Infinitives in the equivalents are presented without the infinitive marker "to," except in instances when "to" is a fixed component of the English equivalent, as in ПО ПРАВДЕ ГОВОРЯ $\langle$ СКАЗАТЬ $\rangle ..$. 'to tell (you) the truth' used as a sentence adverbial.

\section{Articles}

Noun phrases are generally presented without an article, but there are some exceptions. For example, the definite article "the" is provided when an idiom is not used without it (ЦАРCTBO HЕБЕСHOE, sense 1, 'the kingdom of heaven; the heavenly kingdom; the kingdom of God'); the indefinite article "a/an" may be added to indicate that the equivalent cannot be used without an article or specifier of some type (ФОМА НЕВЕРНЫЙ 'a doubting Thomas').

\section{Illustrative Patterns}

Some English equivalents are preceded by a Russian pattern that illustrates the use of the idiom in a sentence. Patterns are used for all verb phrases and for many idioms functioning as subject-complements.

Some Russian idioms that function as predicates do not contain a verb, and the temporal frame of the action must be interpolated from the context. In order to translate the Russian pattern, some temporal context must be assumed. The assumed temporal context is indicated in brackets preceding the English equivalents: for example, the pattern for Н-171 НИ НОГОЙ (sense 1) reads:

\section{$\mathrm{X}$ к Y-у 〈в место $\mathrm{Z}\rangle$ ни ногой $\simeq$ [in present contexts] $\mathbf{X}$ doesn't set $\langle$ never sets〉 foot in $Y$ 's house $\langle$ in place $Z$ etc $\rangle$...}

Occasionally, patterns are provided for context-specific uses of an idiom. For example, Д-247 ПО ДОЛГУ чего 'in order to meet the demands dictated by or intrinsic to sth.' has separate patterns for по долгу службы 'as part of one's 〈s.o.'s $\rangle$ duties 〈responsibilities etc〉...' and по долгу чести 'true to one's honor'. In addition to the equivalents offered in these patterns, some or all of the general equivalents presented for this idiom may also fit по долгу службы and по долгу чести.

\section{Restrictions}

A restriction is presented in square brackets and applies to all equivalents that follow it, up to the next restriction or pattern, if there is one. English equivalents that can be used only in select contexts and should therefore be used cautiously are preceded by the restriction "[lim.]" to indicate that they are to be used only in limited contexts. Other restrictions may point out syntactic or situational limitations, the collocates with which an equivalent may be used, or the particular element of a semantically rich Russian idiom that is stressed by the equivalents that follow; for example:

Б-213 - НАШ БРАТ... [when used as obj or subj] people $\langle$ men, guys, fellows etc $\rangle$ like us $\langle\mathbf{m e}\rangle ;$... [usu. when foll. by an appos] we $\langle\mathbf{u s}\rangle$ writers $\langle$ workers etc $\rangle$; our $\langle\mathbf{m y}\rangle$ fellow writers $\langle$ workers etc $\rangle \ldots$
The entry 3-203 ЗАГОВАРИВАТЬ/ЗАГОВОРИТЬ ЗУБЫ has the following restrictions: [esp. with the goal of avoiding an unpleasant topic]; [esp. with the goal of deceiving the interlocutor]; [esp. with the goal of obtaining sth. from s.o. or extricating o.s. from an uncomfortable situation].

When a Russian idiomatic preposition can be used with both animate and inanimate nouns, but its English equivalents have animate/inanimate restrictions, these restrictions are specified as part of the equivalent; for example:

C-714 • В СТОРОНУ ... 1. кого-чего, чью... in the direction of s.o. $\langle$ sth. $\rangle$; in s.o.'s direction; toward s.o. $\langle$ sth. $\rangle$; s.o.'s way...

\section{Citations AND EXampleS}

Most of the entries in the dictionary are illustrated by citations from Russian and Soviet literature accompanied by a published translation or, in many cases, more than one translation. In the absence of clear, typical, or correctly translated citations, some entries are provided with invented examples. No excerpts from published translations have been retranslated for the purposes of this dictionary. Literary citations and invented examples are generally presented in the same order as their corresponding equivalents.

\section{Style and Conventions}

All citations from works of literature, memoirs, and so forth are followed by the author's name and the number that the given work has been assigned in the Bibliography. The English translation of the citation is followed by the same number plus a letter indicating which translation of the work has been cited (that is, if two translations of a work have been used, they are designated "a" and "b"). Illustrations that do not include an author's name at the end are invented examples provided by the compiler. When selecting literary citations for illustration, minor inaccuracies in translation have been disregarded if they do not harm the sense of the text or the effective illustration of the idiom. It must be kept in mind that a certain amount of freedom is acceptable, and even desirable, in literary translation, as the goal is to make the translation faithful to the original both in meaning and in style. However, some steps have been taken to draw the Russian and English versions of the citations closer together and to clarify points that may not be clear out of context.

In some cases, for example, part of the Russian and/or English text has been ellipted in order to make the texts match better. There is no typographical difference between the author's/translator's ellipsis points and the compiler's.

In other cases a word in a citation is followed by square brackets providing information about that word (for example, that it is a nonce word, a phonetically spelled word, or an ungrammatical, dialectal, regional, or Ukrainian word). Square brackets in citations are also used to indicate pertinent names and pieces of information intended to clarify citation contexts.

Finally, some bracketed additions serve to make the Russian and English variants more similar. It should be noted that such insertions do not imply that the translation is unfaithful; they merely reflect the reality that dictionary contexts are sometimes insufficient to present the situation clearly. Wherever possible, wording found in the cited texts is used for such insertions. 
When a speech impediment is shown through English spelling, as in some citations from Tolstoy, the affected words have been replaced by their correctly spelled counterparts in brackets. For example, in ОТДУВАТЬСЯ СВОИМИ БОКАМИ 'bear the brunt of sth.' the translation of the citation from Tolstoy's War and Peace reads, "This is certainly Scythian warfare. It's all [very] fine-except for those who bear the [brunt] of it." The translator has spelled the bracketed words as "vewy" and "bwunt."

Generally, the transliteration chosen by the translator is preserved for proper names in citations and for the names of characters in plays. However, since the designations of characters in Gogol's The Government Inspector are so different in different translations, the compiler has chosen to make uniform the names of the characters when indicating the speaker in citations. For example, although Городничий is translated as "Mayor," "Chief of Police," and "Prefect" in various translations, it is uniformly rendered "Mayor" in this dictionary.

Occasionally, two or more translations of the same citation are quoted. The user must be aware that translators' approaches differ, and so there may be significant differences in the cited translations. For example, two translations were used for Saltykov-Shchedrin's История одного города (The History of a Town). The names in this book are meaningful. One translator (Susan Brownsberger) chose to translate them into meaningful English names, while the other (I.P. Foote) transliterated them. Thus, "Melancholov" and "Dormousov" in the Brownsberger translation represent the same characters as "Grustilov" and "Bajbakov," respectively, in the Foote translation.

In some cases, the tense forms in the Russian and English versions of a citation do not coincide, but it would require a great amount of context to show why this is so. In such cases, the tense discrepancy has been overlooked. For example, in К-269 СВОДИТЬ/СВЕСТИ КОНЦЫ С КОНЦАМИ (sense 2) 'tie up the loose ends', the beginning of the citation from Zalygin reads «...Мужикам, по их натуре, нужна любая техника...» (present tense) and the translation has "By their nature they [men] needed any sort of science..." (past tense).

Another lack of parallelism in citations concerns the use of quotation marks. Some Russian authors (as Aksyonov and Zinoviev) omit quotation marks in some of their works, while their translators have chosen not to do so. The authors' and translators' choices are retained in the presentation of citations.

Russian citations are presented exactly as they appear in the published text with the exception of a few archaic forms that have been replaced with contemporary ones. For example, in the entry Б-274 НИЧУТЬ... НЕ БЫВАЛО the archaic того же дни in the Gogol citation has been replaced by the contemporary того же дня. In some cases, Western editions of Russian texts have been used as sources for citations. However, since these editions are not as carefully edited as most editions published in Russia and the former Soviet Union, Soviet/Russian editions have occasionally been used to check punctuation, spelling, etc.

The word «Бог» in the citations is capitalized when the source has it capitalized, and lowercase when the source has it lowercase.

The transliteration of proper names in invented examples and Russian names in etymological notes follows the transliteration system used in the Handbook of Russian Literature, edited by Victor Terras. The transliteration of authors' names in the Bibliography follows the spelling currently used by the Library of Congress (with diacritics omitted).

When a Russian author uses a nonstandard form of an idiom, the citation is preceded by the bracketed label "author's usage." When a Russian author uses an idiom either metaphorically or in an atypical context, the citation is preceded by the label "extended usage."

When the English translation of a citation translates the given idiom correctly but in a way that would not apply in most or any other contexts, the translation is preceded by the label "context transl" (contextual translation). Such translations of idioms are not included in the list of equivalents. Citations with contextual translations are presented in order to offer the user examples of creative and original approaches to translation.

When an idiom that originated in a work of Russian literature is illustrated by a citation from that same work, the citation is preceded by the label "source." For example, the idiom P-432 КУВШИННОЕ РЫЛО 'jug snout' originated in Gogol's Dead Souls, so the Dead Souls citation containing the idiom has this label.

English translations of citations are rendered precisely as they occur in the published texts with two exceptions: spellings or orthographic forms that are not found in any mainstream American or British dictionary have been normalized, and the American system for quotation marks has been adopted throughout (that is, double quotes for direct speech and single quotes for a quote within a quote).

In some instances, a translator has come up with an original and creative translation of a Russian idiom or saying. When such translations are offered in this dictionary as regular English equivalents, the translator's version is acknowledged by citing the excerpt in question. For example, the saying ПАНЫ ДЕРУТСЯ, А У ХЛОПЦЕВ 〈ХОЛОПОВ ЧУБЫ ТРЕЩАТ has two equivalents, both of which come from published translations, and both of which are illustrated by their respective citations: "the poor man always gets the blame" comes from a Nabokov citation (translated by Michael Scammell), and "when (the) masters fall out their men get the clout" comes from a Sholokhov citation (translated by Robert Daglish). All the translators' names are, of course, indicated in the Bibliography.

Every citation was cross-referenced to ensure that a citation used to illustrate idiom A, for example, does not have an incorrect equivalent for idiom $\mathrm{B}$. Ideally, and in most cases, the translation of idiom B will be among the equivalents presented in entry B. However, in view of the fact that there are many criteria for a good overall translation apart from idiom translation, this rule has been relaxed in some instances. In no case has a citation been used for one idiom that has an incorrect translation of another idiom in it, but occasionally the translation of the secondary idiom may be bland and read more like the definition of the idiom than an idiomatic equivalent, or be correct only as a contextual translation, not as a general one.

\section{NOTES ON THE ORIGIN OF IDIOMS}

Notes on the source or origin of idioms and other relevant information have been provided in cases where they might contribute to the user's understanding of a Russian idiom and 
facilitate the selection of an English equivalent. Notes have been provided for the following groups of idioms:

1) idioms from the Bible

2) idioms from works of Russian and Western literature

3) idioms from Russian folk tales

4) idioms that are loan translations of phrases from classical or modern languages

5) idioms that are rooted in Russian history, customs, and the Russian way of life.

For Biblical references, the King James Bible was used.

English titles of works of Russian literature are presented as they are known in English translation.

\section{Notes}

1. Mel'čuk, I.A., and A.K. Zholkovsky. Tolkovo-kombinatornyi slovar sovremennogo russkogo iazyka: Opyt seman- tiko-sintaksicheskogo opisaniia russkoi leksiki/Explanatory Combinatorial Dictionary of Modern Russian. Vienna: 1984. (Wiener Slawistischer Almanach. Sonderband 14)

2. Mel'čuk, Igor, and Nadia Arbatchewsky-Jumarie et al. Dictionnaire explicatif et combinatoire du français contemporain. Montréal: Les Presses de l'Université de Montréal, 1984. (Recherches lexico-semantiques 1)

3. Mel'čuk, Igor. Opyt teorii lingvisticheskikh modelei "Smysl ↔ Tekst." Moscow: Nauka, 1974.

4. Chvany, Catherine V. On the Syntax of BE-Sentences in Russian. Cambridge, Mass.: Slavica, 1975.

5. Apresjan, Jurij. Tipy informatsii dlia poverkhnostnosemanticheskogo komponenta modeli "smysl ↔ tekst." Vienna: 1980. (Wiener Slawistischer Almanach, Sonderband 1)

6. Apresjan, Jurij. “Sintaksicheskie priznaki leksem.” Russian Linguistics 9 (2-3), 1985, 289-317. 